\title{
EMPLOYEE PERFORMANCE EVALUATION BY AHP: A CASE STUDY
}

\author{
Rafikul Islam \\ Department of Business Administration \\ International Islamic University Malaysia \\ 53100 Kuala Lumpur, Malaysia \\ rislam@iiu.edu.my \\ Shuib bin Mohd Rasad \\ Inter System Maintenance Services S/B \\ Taman Keramat, Kuala Lumpur, Malaysia \\ shuib_ism@yahoo.com
}

Keywords: employee performance appraisal, AHP

Summary: Employee performance evaluation is designed to assess each individual's contribution to the organization. The performance of individuals against organizational goals determines whether the organization meets its goals. The basic objectives of performance evaluations are two-fold: firstly to reward employees for meeting organizational objectives and secondly to identify which objectives are not met and to develop action plans to ensure they are achieved in future. The present paper uses analytic hierarchy process (AHP) to evaluate employees performances based upon the criteria: quantity/quality of the work, planning/organization, initiative/commitment, teamwork/cooperation, communication and external factors. Each of these criteria has been divided into 3 subcriteria. Two hundred and ninety-four employees of Inter System Maintenance Services Sdn. Bhd. are evaluated on these subcriteria. Overall ranking of the employees has been obtained using the absolute measurement procedure of AHP.

\section{Introduction}

In the organizational context, performance is usually defined as the extent to which an organizational member contributes to achieving the goals of the organization. Performance appraisal is defined as "the process of identifying, evaluating and developing the work performance of the employee in the organization, so that organizational goals and objectives are effectively achieved while, at the same time, benefiting employees in terms of recognition, receiving feedback, and offering career guidance" (Lansbury, 1988). The terms 'performance assessment', 'performance evaluation', 'performance management' are also used to describe the process.

Employee performance appraisal has been practiced by numerous organizations since centuries. Though performance appraisal system has been debated by many, however, overall, it is viewed that performance appraisal is an inseparable part of organizational life. Longenecker and Fink (1999) cited several reasons that formal performance appraisals are to stay in organizations. According to them, formal appraisals are required to justify a wide range of human resource decisions such as pay raises, promotions, demotions, terminations, etc. It is also required to determine employees' training need. The authors cited a recent study on high performance organizations that the practice of performance appraisal was cited as one of the top 10 vehicles for creating competitive advantage. However, sufficient caution should be observed in implementing appraisal system. Ineffective appraisal system can bring many problems including low morale, decreased employee productivity, a lessening of an employee's enthusiasm and support for the organization (Somerick, 1993). 
It is mainly the TQM proponents who oppose the implementation of performance appraisal in organizations (Deming, 1986; Glaser, 1993; Kane and Kane, 1992). Deming believes that 85\% of the factors that affect the employee's performance stem from the system which are beyond the control of the employee, only $15 \%$ of the factors are attributable to the employee. On the other hand, human resource (HR) practitioners do not subscribe the view of TQM proponents. HR practitioners claim that performance appraisal is an essential part of an organizational culture and it is required to assess organizational progress towards goals (Daley, 1993; Landy and Farr, 1983). Aldakhilallah and Parente (2002) have developed a performance appraisal process, called TQMPE (Total Quality Management Performance Evaluation) which they claim as a revised version of the traditional methods of performance appraisal that fits with the philosophy of TQM.

HR experts cite the following benefits of a successful appraisal system:

- Helps taking stocks of an employee's overall performance.

- $\quad$ Enables employee to pinpoint strength and spot weakness.

- $\quad$ Provides an opportunity to motivate employee and encourage for superior performance.

- $\quad$ Lets determine any need for further training.

- Helps setting goals for future superior performance.

There is an enormous body of literature about performance appraisal. In the following, we provide a brief review of some of the recent articles. Effective performance management systems are among the tools for measuring and improving productivity. Productivity improvement is a matter of great concern in numerous organizations - private or public. Organizations at all levels are trying to ensure that their departments and units are doing more with less. In this context, employee performance appraisal system can be considered as a tool that can measure and suggest how to improve productivity (Vallance, 1999).

Roberts (2003) has highlighted the importance of employee participation in the appraisal process. In his article, he has summarized the conceptual foundation of participation including its intrinsic motivational value, the expansion of available information, and the opportunity to interject employee voice. He argues that if employees are confident in the fairness of the appraisal process, they are more likely to accept performance ratings, even adverse ones, if they perceive fair decision making process. In any case, if the employees perceive the process as unfair and not systematic and thorough, it is unlikely that they will accept the outcome of the appraisal exercise.

Suwignjo et al. (2000) have developed Quantitative Models for Performance Measurement Systems (QMPMS), a model for measuring performance with respect to a factor. The model utilizes cognitive maps and analytic hierarchy process to identify factors affecting performance and their relationships, quantify the effect of the factors on performance, and express them quantitatively. However, the model has the limitation to be used as an evaluation tool. Meyer (1995) describes the employee evaluation procedure adopted by a nursing home. The criteria considered are: employee's job attitude, communication skills, and clinical skills. The evaluators used the scoring key for each criterion: Excellent $=4$, Good $=3$, Fair $=2$, and Poor $=1$. However, the author did not elaborate on how the ratings on various criteria were synthesized and converted into a percentage score.

Vallance (1999) describes the performance appraisal methods used in Singapore, Thailand and Philippines (in the context of appraising civil servants) and examines the role of organizational culture on the appraisal process in those countries. Singapore adopts the Potential Appraisal System (PAS) developed originally by Shell Petroleum Company in 1960s. In its present form, it has the following criteria: 'helicopter quality' (meaning that an individual's ability to examine the problems or issues taking all important factors into account), 'intellectual qualities' (power of analysis, imagination and sense of reality), 'results orientation', 'leadership quality' (capacity to motivate, delegate and communicate). In the Thai context, the criteria used are: output of work in terms of quality, quantity and application of work outputs; the ability to manage and perform the work in terms of planning and implementation; the ability to direct and make decisions including meeting deadlines, taking control, coordinating efforts with other organizations, solving problems and resolving conflicts and helping to accomplish the goals of the 
organization; ability to improve work and services, demonstrating new ideas and solutions, identifying and addressing problems and performing work efficiently and effectively. In the Philippines setting, the criteria consists of six areas: management of work, management of people, management of resources, management of linkages, management of constraints and innovativeness.

Milliman et al. (1994) are on the opinion that traditional performance appraisal systems are subjective, simplistic and political. They advocate for 360-degree appraisal system, which requires obtaining information from all sources - internally as well as externally, with whomever the employee has interacted. Internal parties include supervisors, top management, subordinates, co-workers and representative from other department who interacts with the employee. On the other hand, external parties include clients, suppliers, consultants, and community officials. In short, anyone who has useful information on how the employee does the job may be a source in the 360-degree appraisal. In the case study conducted on the employees of East Carolina University, Mani (2002) has shown that employees' perception of the fairness of the appraisal systems is related to trust and satisfaction with their supervisors but not with compliance with the program's procedures.

In this paper, we have developed a case study on employee performance appraisal using AHP. Though AHP has been applied in numerous real settings, but there is little evidence that AHP has been applied in employee performance evaluation. Only Saaty (1990) in some of his early papers pointed out how the absolute measurement procedure of AHP can be applied to evaluate employees' performances. But till date there has not been any real application of the methodology in evaluating employees' performances. This paper attempts to fill up the gap. Though there is a dearth of applications of AHP in performance appraisal, however, there have been a number of applications of AHP in evaluating organizations' branches or internal units. Following are some of the applications of AHP as an evaluation tool.

Taylor III et al. (1998) have described a case study where AHP has been used to evaluate personnel for selection. In particular, the study described the procedure to select a college dean at Texas A\&M University at Kingsville. The selection committee evaluated 33 prospective candidates on the basis of the four criteria: experience with AACSB accreditation process, experience in an administrative position, a good publication record, and proven ability at fund raising. However, the selection committee encountered difficulty at the huge number of pairwise comparisons in the process of comparing all the 33 candidates. Bahurmoz (2003) has applied AHP to select candidates for sending overseas to do graduate studies who will later become teachers at Dar Al-Hekma women's college in Jeddah, Saudi Arabia.

Chan and Lynn (1991) have used AHP to propose a model for evaluation of several branches of a firm. They argued that the traditional performance evaluation model based upon single measurement criterion (which is mostly return on investment) ignores several factors that are important for performance evaluation. In their analysis, to evaluate the overall performance of the branches, they have used the following set of criteria: profitability, productivity, marketing effectiveness, operating effectiveness, hedging effectiveness, employee morale, customer satisfaction, product, technology innovation, and operating efficiency. Rangone (1996) has used AHP to measure and compare the overall performance of different manufacturing departments within the same company on the basis of multi-attribute financial and non-financial criteria. The author has discussed how AHP can help managers to assess and compare the overall contribution provided by each manufacturing department to achieve the manufacturing objective, by linking the competitive priorities to performance measure at every level of the manufacturing organizational structure, and by addressing tradeoffs among them.

As mentioned before, employee appraisal system has been criticized by many. Some of the criticisms are that the system assumes a false degree of measurement accuracy, engenders dysfunctional employee conflict and competition, assigns an inordinate amount of responsibility for poor performance to individual employees while undervaluing the importance of the overall work process, underemphasizes the importance of teamwork (Deming, 1986). Others refer to the system as 'a lot of work, without a lot of value'. It is to that extent that some people held the view that employee performance appraisal system is inherently flawed. Gray (2002) writes: “... performance appraisals don't produce more competent, loyal workers because the practice is inherently flawed”. Proponents of performance appraisal system argue 
that the effects of many of the negative factors can be diminished by following certain guidelines (Roberts, 2003). Before presenting our case study, some of the guidelines for successful implementation of appraisal system are discussed below:

\section{Employee Performance Appraisal Guidelines}

Employee participation: In any case, if the employees perceive the appraisal system as biased, unfair and lacks rigour, then it is unlikely that they will accept the outcomes of the system. Participation gives an opportunity to the employees to raise their voice into the appraisal process. Performance standards, criteria for evaluation and the evaluation form itself - all can be developed with the help of employees. Greater employee participation generates an atmosphere of cooperation and support, which facilitates the development of a coaching or counseling relationship, thereby reducing appraisal related tension and rater-ratee conflict (Jordan, 1992). At Hamilton Standard, the feedback from a number of employees helped to clarify job roles and expectations - frequent sources of disagreement between employees from different functional areas. Somerick (1993) suggested having a dialogue session between the manager and the employees. Concerning to the appraisal system, if any problem occurs, that can be discussed in the dialogue session immediately - not months later when the employee's performance has been rated and documented in his/her personal file.

Developing performance standards: Standards to be developed that measure the essential job duties and responsibilities. Once again, employee participation facilitates developing reliable, valid, fair and useful performance standards.

Goal setting: Goal setting has been powerful motivational tool. Majority of goal setting research has been carried out in non-appraisal settings. Goal setting consists of performance goals that are specific, moderately challenging and accepted. Goal setting within performance appraisal has been associated with greater appraisal satisfaction and increased performance (Dobbins et al., 1990). Stevens (1990) states that: "...assign employees a series of goals to be accomplished in the course of a year. When annual reviews are held, rate the employees' progress in achieving these goals.”

Sound performance appraisal interview: If the appraisal interview is conducted poorly, the efficacy of the appraisal system is lost. The interviewer must be aware about sensitivity to employee needs for privacy and confidentiality. It is of utmost importance to provide undivided attention during the interview and reserve adequate time for a full discussion of the issues (Roberts, 1994). "Last spring my supervisor was too busy to evaluate me, so I have no idea what kind of evaluation if any was turned in at all”, comments a disgusted employee at East Carolina University (Mani, 2002, p.150). To encourage employees to participate in the evaluation, Krug (1998) suggested asking open-ended questions, i.e., the questions that cannot be answered with a simple yes, or no. Particularly, he suggested instead of asking a question like, "Do you enjoy your job?”, ask, "How do you feel about working in this company?” The latter question requires a more thoughtful and informative answer.

Self evaluation: This is required to resolve employees' general complaint "Our appraisal process does not take any assessment of myself into account. I would at least like to share my thoughts on what I have accomplished and where I might improve". Self evaluation provides employees an opportunity to systematically assess their performance. Studies have indicated that self evaluation increases employees' perceived fairness on the appraisal process. Employees can evaluate themselves by completing their own appraisal form and presenting the draft for discussion with the evaluator. McCarthy (2000) comments that employees who have an opportunity to asses their own performance often come up with creative solutions that would not have surfaced in the one-sided managerial evaluation. Pam Perry, vice president of human resources for CB Richard Ellis says (cited in McCarthy, 2000, p. 25)

I have my staff write their own reviews; they do the rating and include their comments, then we sit down together and go over them. It eliminates the debate over who is right and who is wrong 
and allows us to focus on what's important. It's valuable for employees to express their thoughts about their performance in writing.

Management feedback: Management's feedback is required for a common sense reason. When the employees do good jobs, they expect a pat on their backs (positive feedback); on the other hand, if the poor performers do not receive any constructive feedback which tell them to improve, they will think that the present level of performance is accepted in the organization and they may not put extra efforts to improve. Camardella (2003, p. 105) writes:

Evaluating each employee as average, without specifically mentioning strengths and weaknesses, diminishes the value of the appraisal process. When an employee's strengths and weaknesses are explained, the employee can build on his or her strengths and correct his or her weaknesses. Employees cannot improve their job performance unless they are told where their performance is inadequate.

To have an effective performance appraisal system, there must be formal and informal performance feedback. Roberts (2003, p. 93) echoes Camardella by saying:

Feedback is essential in gaining the maximum benefits from goal setting. Without feedback, employees are unable to make adjustments in job performance or receive positive reinforcement for effective job behavior. Effective performance feedback is timely, specific, behavioral in nature, and presented by a credible source. Performance feedback is effective in changing employee work behavior and enhances employee job satisfaction and performance.

In the feedback, what the employee is doing right should be emphasized. Focus also should be paid on employee's strength. Provide a short list of areas where the employee needs to improve, highlight the most important ones to be improved first.

Develop user-friendly procedure: Performance criteria and rating procedure should be simple enough and they should be well understood by the raters and ratees. Performance criteria should encompass the key aspects of employee's job. If any key aspect is ignored, then it sends the message that that is unimportant and can be ignored.

Design specific and relevant appraisals: Sometimes employees complain on appraisal system by saying “Our company uses the same appraisal for all positions. I feel that the things I'm measured on don't have much to do with what I do from day to day” (McCarthy, 2000, p. 24). Appraisal system will be successful only when the items appraised address the requirements and essential functions on the job. The criteria used should be specific and directly related to the job.

Evaluator training: The research conducted by the American Management Association reveals that the main reason for employee and supervisor's frustration with the performance appraisal forces is that a large number of managers are poorly trained in how to give feedback to employees (cited in Krug, 1998). The person who conducts the appraisal exercise should receive extensive training in goal setting, setting performance standards, conducting interviews, providing feedback, avoiding rating biases, etc. He/she should know how to conduct appraisals accurately, consistently, fairly and objectively. In particular, top management must be aware about the competency level of the raters as mentioned by Martin and Bartol (1998, p. 226):

... a review may suggest that a rater who consistently gives all high ratings would be committing a leniency error. On the other hand, a rater who rated most employees low may have fallen prey to the stringency error, and one who entered most employees in the middle of the scale may be demonstrating the error of central tendency. 
Revise performance appraisal process: No system is permanent and appraisal system is not an exception. Feedback on the appraisal process should be regularly solicited from both supervisors and employees. Longenecken and Fink (1999, p. 22) state:

It is important to systematically and regularly review system operations to make sure that process and practices are being followed and effective. Examples of measures that can be used to assess the health of your appraisal system include employee acceptance and trust of the appraisal system.

Once David C. Martin and Kathryn M. Bartol were invited by a governmental agency to revise its employee appraisal system. This was because the current system had been used for many years and at that time, the average individual performance score was 98 out of 100 points. As result, the agency could no longer make good personnel decisions based on the performance appraisal results since everyone in the organization was outstanding! (Martin and Bartol, 1998)

The origins of performance appraisal have been traced to the third century AD in China, when philosopher Sin Yu reportedly criticized a rater employed by the Wei Dynasty for rating employees according to his own personal likes and dislikes rather than on the basis of individual merit (Patten, 1977). Modern appraisals are applied, for the first time, by US army in 1813 (Petrie, 1950).

There are many methods available in the performance appraisal. Some are formal while others are informal. Informal appraisals involve the assessment of an individual's performance outside any formal structure. Employees are subject to both conscious and unwitting assessment by their supervisors on a daily basis. Much of this assessment is subjective and may be affected by such factors as the ability of the employee to get on with his or her supervisor, his or her reactions under pressure, his or her appearance, degree of organization, levels of attentiveness and interest. While these sorts of informal assessments are difficult to avoid, contemporary wisdom suggests that formal appraisals ought not to be trait based, but be directly related to the specific duties of positions (Hallyer and Brewer, 1991). Formal appraisal system evaluates performance of employee based upon explicit criteria - qualitative as well as quantitative. Some of the formal evaluation techniques are graphic rating scales, behaviorally anchored rating scales (BARS), behavior observation scales. A comprehensive description of these methods can be found in Murphy and Cleveland (1991). The following section provides a case study on how performance appraisal can be conducted using the AHP.

\section{A Case Study}

Inter System Maintenance Services Sdn. Bhd. (abbreviated as ISMS) was registered on 3rd July, 1986 at the Registrar of Business Office in Kuala Lumpur. ISMS offers the following type of maintenance and cleaning services to its clients:

- Cleaning and maintenance of offices and buildings

- Cleaning and maintenance of office and building exteriors

- Cleaning and maintenance of all types of floors and interiors

- Cleaning of all type of carpeted floorings

- Area maintenance including landscape and gardens

- Cleaning drains and grass cutting

- Refuse/litter collections

The company has three branches located at Kuala Lumpur, Malacca, and Pahang. The mission of the company is the following:

- To provide quality, efficient, and effective services to its clients

- To build excellent and lasting business rapport with clients, and

- To be successful and highly respected 'bumiputra' company 
To succeed in the competitive business market, the company strives to differentiate itself by providing superior quality services to its clients. The Kuala Lumpur unit of the company has about 300 employees working at various operational levels. Their works are closely monitored by a number of supervisors. The performance of the company depends heavily on the performance of those employees.

The main purpose of the paper is to evaluate the performance of the operational level employees of the company. It was widely speculated that the present performance appraisal system adopted by the company lacked objectivity. Therefore, the company needs an objective measurement procedure which is capable of incorporating objective as well as subjective factors into the evaluation process and it provides a measurement of the employees overall performance that is fairly accurate. It is the analytic hierarchy process (AHP) that can precisely meet the necessity of the company. The first author of this paper made a presentation of the technique before the company management and explained how the technique can be applied in the appraisal process. With the help of AHP, the company has revamped its performance appraisal process. The flowchart of the new process has been shown in Figure 1.

\subsection{Using Absolute Measurement Procedure of AHP at ISMS}

When the first author introduced the absolute measurement procedure of AHP to the top management of the company, they recommended to the HR manager to implement the technique as the performance evaluation tool. Below are the steps of absolute measurement process adopted by ISMS.

Step 1: Identify the criteria, subcriteria and employees (to be evaluated) for evaluation and put them into the AHP hierarchy.

Step 2: Calculate the weights of the decision criteria by the relative measurement of AHP, i.e., construct the pairwise comparison matrix for all the criteria and compute the normalized principal right eigenvector of the matrix. This vector gives the weights of the criteria. Divide the criteria into subcriteria and calculate the weights of these subcriteria in the same manner. Multiply these weights by the weights of the parent criteria.

Step 3: Divide each subcriterion into several intensities or grades. Set priorities on the intensities by comparing them pairwise under each subcriterion. Multiply these priorities by the priority of the parent subcriterion.

If $\mathrm{p}_{\mathrm{i}}, \mathrm{i}=1,2, \ldots, \mathrm{m}$ is the weight of the ith main criterion, $\mathrm{q}_{\mathrm{ij}}, \mathrm{i}=1,2, \ldots, \mathrm{m}, \mathrm{j}=1,2, \ldots, \mathrm{n}$ is the weight of the jth subcriterion of the ith criterion, then the global weight $r_{\mathrm{kg}}$ of the kth intensity, $\mathrm{k}$ $=1,2, \ldots, \mathrm{s}$ with respect to the jth subcriterion of the ith criterion is

$$
\mathrm{r}_{\mathrm{kg}}=\mathrm{p}_{\mathrm{i}} \times \mathrm{q}_{\mathrm{ij}} \times \mathrm{r}_{\mathrm{k}} \quad \ldots(1)
$$

where $r_{k}$ is the local weight of the kth intensity.

Step 4: Take one employee at a time and measure his/her performance intensity under each subcriterion. Add the global priorities of the intensities for the employee. Repeat the process for all the employees.

The AHP hierarchy of the newly adopted evaluation scheme has been shown in Figure 2a and 2b. Figure 2a shows only the criteria and subcriteria. It is to be noted that ISMS has considered exactly three subcriteria for all the six major criteria. Figure $2 b$ shows the criteria, subcriteria and the employees to be evaluated. The full forms and necessary details of the criteria and subcriteria are provided in Table 1.

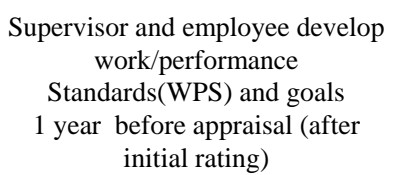




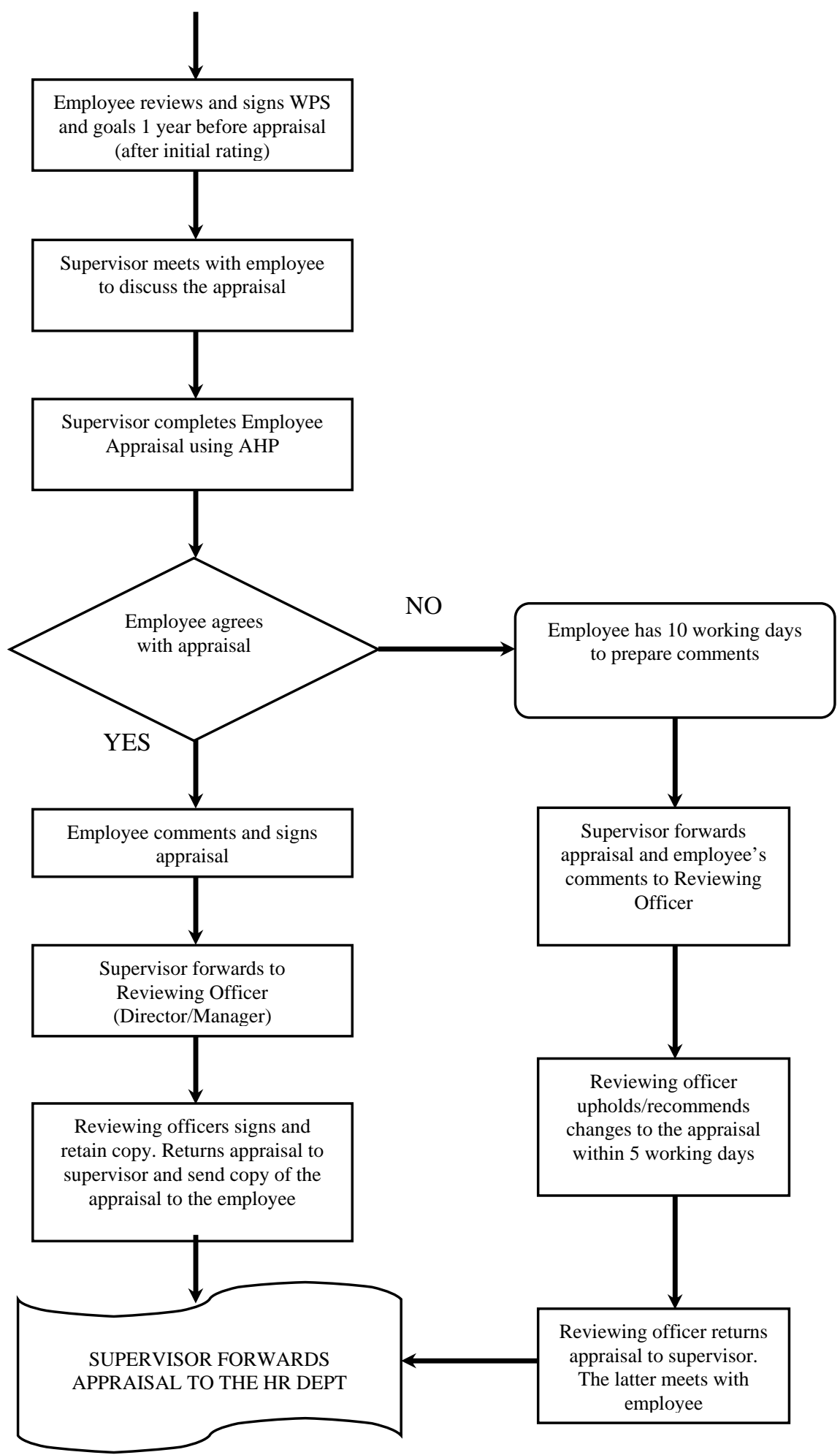

Figure 1: Flowchart of the New Performance Appraisal System at ISMS 


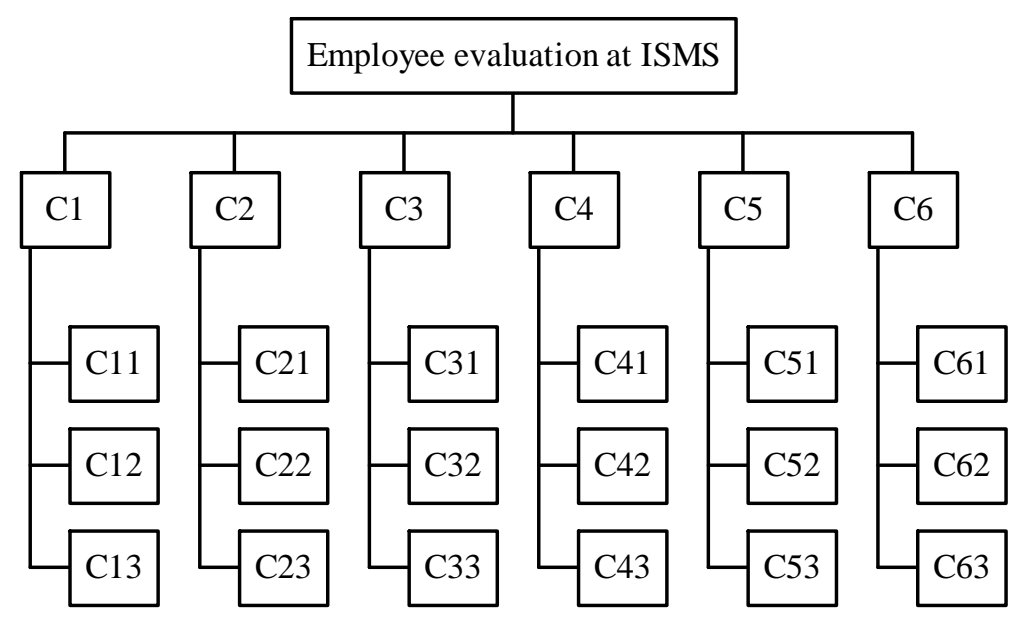

Figure 2a: The Hierarchy of the Criteria and Subcriteria of the Evaluation Process

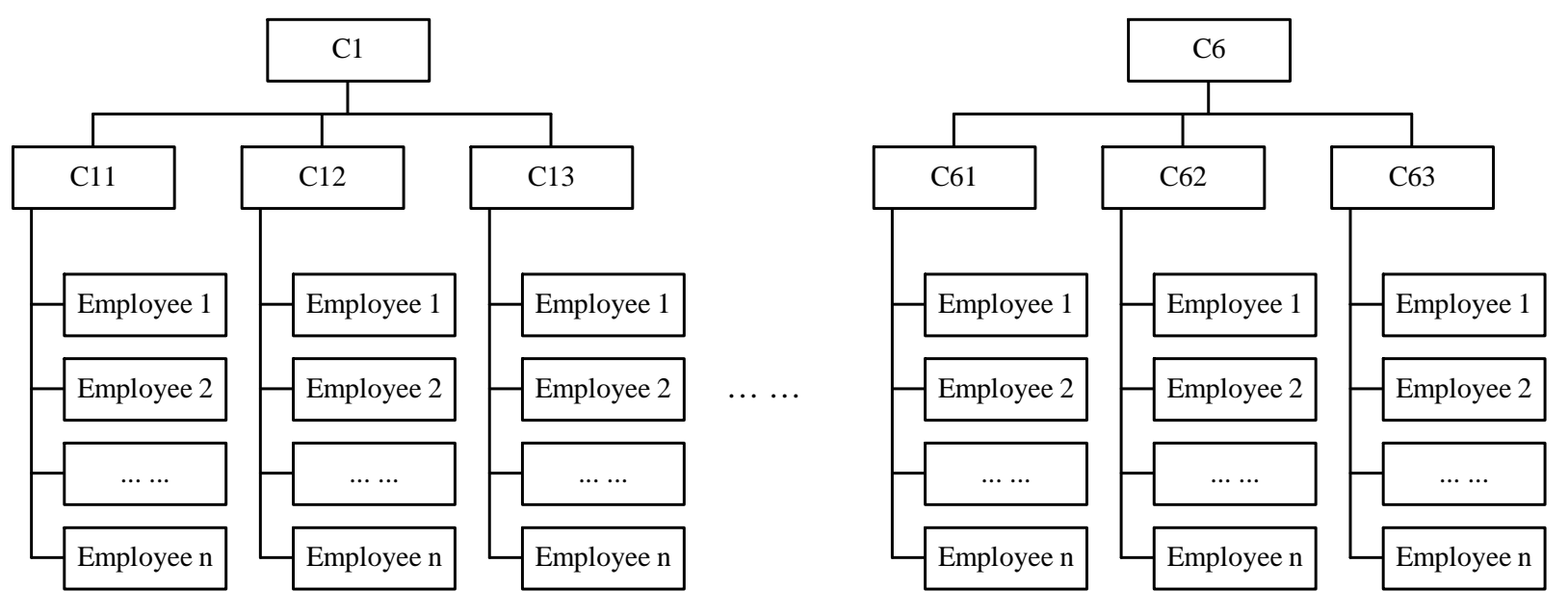

Figure 2b: The Partial Hierarchy Consisting of the Employees 
Table 1: Criteria and Subcriteria of the Performance Appraisal Process at ISMS

\begin{tabular}{|c|c|c|}
\hline Criteria & Meaning & Subcriteria \\
\hline $\begin{array}{l}\text { Quality/Quantity of } \\
\text { work }\left(\mathrm{C}_{1}\right)\end{array}$ & $\begin{array}{l}\text { This criterion includes completion of tasks } \\
\text { in a thorough, accurate and timely manner } \\
\text { that achieve expected results. Individuals } \\
\text { exhibit concern for the goals and needs of } \\
\text { the company and others that depends on } \\
\text { services/products, and handles multiple } \\
\text { responsibilities in an effective manner. This } \\
\text { is essential as the company participates in } \\
\text { the cleaning industry; quality of services is } \\
\text { of utmost importance to gain clients' } \\
\text { confidence. }\end{array}$ & $\begin{array}{l}\text { - } \text { Complete tasks }\left(\mathrm{C}_{11}\right) \\
\text { - } \text { Concern for goals }\left(\mathrm{C}_{12}\right) \\
\text { - } \text { Multiple assignments }\left(\mathrm{C}_{13}\right)\end{array}$ \\
\hline $\begin{array}{l}\text { Planning/organization } \\
\qquad\left(\mathrm{C}_{2}\right)\end{array}$ & $\begin{array}{l}\text { Planning for usage of organization's limited } \\
\text { resources and organizing himself/herself to } \\
\text { carryout the activities are deemed important } \\
\text { at ISMS. Furthermore, individuals are } \\
\text { expected to identify resources required to } \\
\text { meet goals and objectives. It is ideal for } \\
\text { individuals to seek guidance whenever the } \\
\text { goals and priorities are unclear. Planning in } \\
\text { terms of manpower and other resources } \\
\text { required to undertake respective project is } \\
\text { essential to maximize resource utilization. }\end{array}$ & $\begin{array}{l}\text { - } \text { Clear objectives }\left(\mathrm{C}_{21}\right) \\
\text { - Identify resources }\left(\mathrm{C}_{22}\right) \\
\text { - Seek guidance }\left(\mathrm{C}_{23}\right)\end{array}$ \\
\hline $\begin{array}{l}\text { Initiative/commitment } \\
\qquad\left(\mathrm{C}_{3}\right)\end{array}$ & $\begin{array}{l}\text { This criterion evaluates individual } \\
\text { responsibility when performing duties. The } \\
\text { employees must demonstrate an ability to } \\
\text { offer assistance to others, to support the } \\
\text { goals and objectives of the company. } \\
\text { Employee must have an ability to perform } \\
\text { with minimal supervision and meets } \\
\text { expectations. }\end{array}$ & $\begin{array}{l}\text { - Demonstrated commitment as } \\
\text { a responsible person }\left(\mathrm{C}_{31}\right) \\
\text { - } \text { Minimal supervision }\left(\mathrm{C}_{32}\right) \\
\text { - } \text { Meets expectations }\left(\mathrm{C}_{33}\right)\end{array}$ \\
\hline $\begin{array}{l}\text { Teamwork/cooperation } \\
\qquad\left(\mathrm{C}_{4}\right)\end{array}$ & $\begin{array}{l}\text { This includes maintaining harmonious and } \\
\text { effective work relationships with co- } \\
\text { workers. Individuals must be able to adapt to } \\
\text { changing priorities and demands. He/she } \\
\text { must also be willing to share information } \\
\text { and resources with others in order to } \\
\text { promote positive and collaborative work } \\
\text { environment. }\end{array}$ & $\begin{array}{l}\text { - Harmonious work }\left(\mathrm{C}_{41}\right) \\
\text { - Adapts to changes }\left(\mathrm{C}_{42}\right) \\
\text { - Share information resources } \\
\left(\mathrm{C}_{43}\right)\end{array}$ \\
\hline $\begin{array}{l}\text { Communication } \\
\left(\mathrm{C}_{5}\right)\end{array}$ & $\begin{array}{l}\text { This is concerned about how effectively the } \\
\text { employee conveys information and ideas } \\
\text { both orally and in writing. Individuals must } \\
\text { also be able to listen carefully and seeks } \\
\text { clarification to ensure clear understanding } \\
\text { whenever task is given. }\end{array}$ & $\begin{array}{ll}\text { - } & \text { Conveys information/idea } \\
& \left(\mathrm{C}_{51}\right) \\
\text { - } & \text { Conflict resolution }\left(\mathrm{C}_{52}\right) \\
\text { - } & \text { Seeks clarification }\left(\mathrm{C}_{53}\right)\end{array}$ \\
\hline $\begin{array}{l}\text { External factors } \\
\qquad\left(\mathrm{C}_{6}\right)\end{array}$ & $\begin{array}{l}\text { ISMS is not a company which only seeks } \\
\text { profit, the company strives to contribute to } \\
\text { greater society in several ways. }\end{array}$ & $\begin{array}{l}\text { - Contribution to society }\left(\mathrm{C}_{61}\right) \\
\text { - Involvement at the non } \\
\text { organizational activities }\left(\mathrm{C}_{62}\right) \\
\text { - Promotes the company }\left(\mathrm{C}_{63}\right) \\
\end{array}$ \\
\hline
\end{tabular}




\subsection{Determining the Criteria and Subcriteria Weights}

The HR manager in consultation with the managing director of the company developed the following pairwise comparison matrices to determine the criteria and subcriteria weights. The weights for all the pairwise comparison matrices were computed using Expert Choice decision support software.

\begin{tabular}{|c|cccccc|c|}
\hline & $\mathrm{C}_{1}$ & $\mathrm{C}_{2}$ & $\mathrm{C}_{3}$ & $\mathrm{C}_{4}$ & $\mathrm{C}_{5}$ & $\mathrm{C}_{6}$ & Weights \\
\hline $\mathrm{C}_{1}$ & 1 & 8 & 6 & 7 & 4 & 7 & 0.480 \\
$\mathrm{C}_{2}$ & & 1 & 7 & 6 & 4 & 7 & 0.240 \\
$\mathrm{C}_{3}$ & & & 1 & 7 & 5 & 6 & 0.135 \\
$\mathrm{C}_{4}$ & & & & 1 & 6 & 8 & 0.077 \\
$\mathrm{C}_{5}$ & & & & 1 & 8 & 0.049 \\
$\mathrm{C}_{6}$ & & & & 1 & 0.019 \\
\hline \multicolumn{7}{c}{$\mathrm{CR}=0.40$} \\
\hline
\end{tabular}

\begin{tabular}{|c|ccc|c|}
\hline $\mathrm{C}_{1}$ & $\mathrm{C}_{11}$ & $\mathrm{C}_{12}$ & $\mathrm{C}_{13}$ & Wts. \\
\hline $\mathrm{C}_{11}$ & 1 & 8 & 9 & 0.804 \\
$\mathrm{C}_{12}$ & & 1 & 2 & 0.122 \\
$\mathrm{C}_{13}$ & \multicolumn{5}{|c|}{$\mathrm{CR}=0.04$} \\
\hline \multicolumn{5}{|c}{} \\
\hline
\end{tabular}

\begin{tabular}{|c|ccc|c|}
\hline $\mathrm{C}_{2}$ & $\mathrm{C}_{21}$ & $\mathrm{C}_{22}$ & $\mathrm{C}_{23}$ & Wts. \\
\hline $\mathrm{C}_{21}$ & 1 & 4 & 8 & 0.699 \\
$\mathrm{C}_{22}$ & & 1 & 5 & 0.237 \\
$\mathrm{C}_{23}$ & \multicolumn{5}{|c|}{$\mathrm{CR}=0.09$} \\
\hline \multicolumn{5}{|c|}{} \\
\hline
\end{tabular}

\begin{tabular}{|c|ccc|l|}
\hline $\mathrm{C}_{3}$ & $\mathrm{C}_{31}$ & $\mathrm{C}_{32}$ & $\mathrm{C}_{33}$ & Wts. \\
\hline $\mathrm{C}_{31}$ & 1 & 8 & 9 & 0.804 \\
$\mathrm{C}_{32}$ & & 1 & 2 & 0.122 \\
$\mathrm{C}_{33}$ & \multicolumn{5}{|c|}{$\mathrm{CR}=0.04$} \\
\hline \multicolumn{5}{|c|}{} \\
\hline
\end{tabular}

\begin{tabular}{|c|ccc|c|}
\hline $\mathrm{C}_{4}$ & $\mathrm{C}_{41}$ & $\mathrm{C}_{42}$ & $\mathrm{C}_{43}$ & Wts. \\
\hline $\mathrm{C}_{41}$ & 1 & 3 & 8 & 0.653 \\
$\mathrm{C}_{42}$ & & 1 & 6 & 0.285 \\
$\mathrm{C}_{43}$ & \multicolumn{5}{|c|}{$\mathrm{CR}=0.07$} \\
\hline \multicolumn{5}{|c|}{} \\
\hline
\end{tabular}

\begin{tabular}{|c|ccc|c|}
\hline $\mathrm{C}_{5}$ & $\mathrm{C}_{51}$ & $\mathrm{C}_{52}$ & $\mathrm{C}_{53}$ & Wts. \\
\hline $\mathrm{C}_{51}$ & 1 & 8 & 8 & 0.796 \\
$\mathrm{C}_{52}$ & & 1 & 2 & 0.125 \\
$\mathrm{C}_{53}$ & \multicolumn{5}{|c|}{$\mathrm{CR}=0.05$} \\
\hline \multicolumn{5}{|c|}{} \\
\hline
\end{tabular}

\begin{tabular}{|c|ccc|l|}
\hline $\mathrm{C}_{6}$ & $\mathrm{C}_{61}$ & $\mathrm{C}_{62}$ & $\mathrm{C}_{63}$ & Wts. \\
\hline $\mathrm{C}_{61}$ & 1 & 8 & 9 & 0.798 \\
$\mathrm{C}_{62}$ & & 1 & 3 & 0.138 \\
$\mathrm{C}_{63}$ & \multicolumn{5}{|c|}{$\mathrm{CR}=0.10$} \\
\hline \multicolumn{5}{|c|}{}
\end{tabular}

The pairwise comparison matrix for the intensities namely, excellent (E), good (G), average (A), satisfactory (S), and poor (P) is the following:

\begin{tabular}{|c|ccccc|c|}
\hline & E & G & A & S & P & Weights \\
\hline E & 1 & 3 & 5 & 6 & 8 & 0.501 \\
G & & 1 & 3 & 5 & 6 & 0.262 \\
A & & & 1 & 3 & 5 & 0.133 \\
S & & & & 1 & 3 & 0.067 \\
P & & & & 1 & 0.036 \\
\hline \multicolumn{7}{c}{ CR $=0.06$} \\
\hline
\end{tabular}

The global weights of the intensities (using the formula (1)) are shown in Table 2.

Table 2: Global Weights of the Intensities

\begin{tabular}{|l|c|c|l|l|l|l|l|l|l|l|l|l|}
\hline \multirow{2}{*}{ Int. } & \multicolumn{3}{|c|}{$\mathrm{C}_{1}$} & \multicolumn{3}{c|}{$\mathrm{C}_{2}$} & \multicolumn{3}{c|}{$\mathrm{C}_{3}$} & \multicolumn{3}{c|}{$\mathrm{C}_{4}$} \\
\cline { 2 - 15 } & $\mathrm{C}_{11}$ & $\mathrm{C}_{12}$ & $\mathrm{C}_{13}$ & $\mathrm{C}_{21}$ & $\mathrm{C}_{22}$ & $\mathrm{C}_{23}$ & $\mathrm{C}_{31}$ & $\mathrm{C}_{32}$ & $\mathrm{C}_{33}$ & $\mathrm{C}_{41}$ & $\mathrm{C}_{42}$ & $\mathrm{C}_{43}$ \\
\hline $\mathrm{E}$ & $0.1933^{2}$ & 0.0293 & 0.0178 & 0.0840 & 0.0285 & 0.0077 & 0.0544 & 0.0083 & 0.0050 & 0.0252 & 0.0110 & 0.0024 \\
\hline $\mathrm{G}$ & 0.1011 & 0.0153 & 0.0093 & 0.0440 & 0.0149 & 0.0040 & 0.0284 & 0.0043 & 0.0026 & 0.0132 & 0.0057 & 0.0013 \\
\hline $\mathrm{A}$ & 0.0513 & 0.0078 & 0.0047 & 0.0223 & 0.0076 & 0.0020 & 0.0144 & 0.0022 & 0.0013 & 0.0067 & 0.0029 & 0.0006 \\
\hline $\mathrm{S}$ & 0.0259 & 0.0039 & 0.0024 & 0.0112 & 0.0038 & 0.0010 & 0.0073 & 0.0011 & 0.0007 & 0.0034 & 0.0015 & 0.0003 \\
\hline $\mathrm{P}$ & 0.0139 & 0.0021 & 0.0013 & 0.006 & 0.002 & 0.0006 & 0.0039 & 0.0006 & 0.0004 & 0.0018 & 0.0008 & 0.0002 \\
\hline \multicolumn{9}{|c|}{} & $0.480 \times 0.804 \times 0.501$ & 0.1933 \\
\hline
\end{tabular}


Table 2: Continued

\begin{tabular}{|l|c|c|c|c|c|c|}
\hline \multirow{2}{*}{ Int. } & \multicolumn{3}{|c|}{$\mathrm{C}_{5}$} & \multicolumn{3}{c|}{$\mathrm{C}_{6}$} \\
\cline { 2 - 7 } & $\mathrm{C}_{51}$ & $\mathrm{C}_{52}$ & $\mathrm{C}_{53}$ & $\mathrm{C}_{61}$ & $\mathrm{C}_{62}$ & $\mathrm{C}_{63}$ \\
\hline E & 0.0195 & 0.0031 & 0.0019 & 0.0076 & 0.0013 & 0.0006 \\
\hline G & 0.0102 & 0.0016 & 0.0010 & 0.0040 & 0.0007 & 0.0003 \\
\hline A & 0.0052 & 0.0008 & 0.0005 & 0.0020 & 0.0003 & 0.0002 \\
\hline S & 0.0026 & 0.0004 & 0.0003 & 0.0010 & 0.0002 & 0.0001 \\
\hline P & 0.0014 & 0.0002 & 0.0001 & 0.0005 & 0.0001 & 0.0001 \\
\hline
\end{tabular}

All the supervisors were instructed to use AHP to conduct performance appraisal. Prior to taking assignments, all the supervisors were briefed about AHP. Table 3 provides the evaluation score of the 25 employees working under one supervisor. Due to space limitation, scores of the employees working under other supervisors are not provided. The first column of the table provides the abbreviated names of the employees (arranged alphabetically). As we observe, this supervisor has committed leniency error on some criteria (e.g., $\mathrm{C}_{11}, \mathrm{C}_{31}, \mathrm{C}_{33}, \mathrm{C}_{41}, \mathrm{C}_{51}, \mathrm{C}_{63}$ ) and stringency error on other criteria (e.g., $\mathrm{C}_{12}, \mathrm{C}_{32}, \mathrm{C}_{52}$, $\mathrm{C}_{62}$ ). The management has drawn the supervisor's attention on the matter.

\section{Table 3: Performance Rating of 25 Employees}

\begin{tabular}{|c|c|c|c|c|c|c|c|c|c|c|c|c|c|c|c|c|c|c|}
\hline \multirow[t]{2}{*}{ Empl. } & \multicolumn{3}{|c|}{$\mathrm{C}_{1}$} & \multicolumn{3}{|c|}{$\mathrm{C}_{2}$} & \multicolumn{3}{|c|}{$\mathrm{C}_{3}$} & \multicolumn{3}{|c|}{$\mathrm{C}_{4}$} & \multicolumn{3}{|c|}{$\mathrm{C}_{5}$} & \multicolumn{3}{|c|}{$\mathrm{C}_{6}$} \\
\hline & $\mathrm{C}_{11}$ & $\mathrm{C}_{12}$ & $\mathrm{C}_{13}$ & $\mathrm{C}_{21}$ & $\mathrm{C}_{22}$ & $\mathrm{C}_{23}$ & $\mathrm{C}_{31}$ & $\mathrm{C}_{32}$ & $\mathrm{C}_{33}$ & $\mathrm{C}_{41}$ & $\mathrm{C}_{42}$ & $\mathrm{C}_{43}$ & $\mathrm{C}_{51}$ & $\mathrm{C}_{52}$ & $\mathrm{C}_{53}$ & $\mathrm{C}_{61}$ & $\mathrm{C}_{62}$ & $\mathrm{C}_{63}$ \\
\hline AAD & G & $S$ & G & $\mathrm{E}$ & A & A & G & $S$ & $\mathrm{G}$ & G & $\mathrm{S}$ & $\mathrm{S}$ & G & $\mathrm{P}$ & G & G & $S$ & G \\
\hline ABA & $E$ & $P$ & $G$ & $E$ & $\mathrm{~S}$ & A & $E$ & $\mathrm{P}$ & G & G & $\mathrm{S}$ & $\mathrm{S}$ & G & $\mathrm{S}$ & G & G & $\mathrm{S}$ & $G$ \\
\hline AGS & $E$ & $P$ & $G$ & G & A & $S$ & $E$ & $\mathrm{P}$ & $G$ & G & $\mathrm{S}$ & $\mathrm{S}$ & $G$ & $\mathrm{P}$ & G & $G$ & $\mathrm{~S}$ & G \\
\hline BA & G & $S$ & $G$ & G & $\mathrm{S}$ & A & $G$ & $G$ & $G$ & G & A & $\mathrm{S}$ & A & $\mathrm{S}$ & A & A & $\mathrm{S}$ & $G$ \\
\hline BA & $E$ & $\mathrm{P}$ & E & G & $\mathrm{S}$ & A & E & $\mathrm{P}$ & E & $\mathrm{E}$ & A & $\mathrm{S}$ & A & $\mathrm{S}$ & A & A & $\mathrm{S}$ & G \\
\hline BB & $E$ & $P$ & G & A & $S$ & A & $E$ & $\mathrm{P}$ & $G$ & G & $S$ & $\mathrm{~S}$ & A & $S$ & A & A & $S$ & G \\
\hline BK & $E$ & $\mathrm{P}$ & G & A & $\mathrm{S}$ & A & $E$ & $\mathrm{P}$ & $\mathrm{G}$ & G & A & $\mathrm{S}$ & A & $\mathrm{P}$ & A & A & $\mathrm{S}$ & G \\
\hline CI & $G$ & $P$ & G & $E$ & $S$ & A & G & $\mathrm{P}$ & $G$ & $G$ & $\mathrm{~S}$ & $\mathrm{~S}$ & $G$ & $\mathrm{P}$ & $G$ & $G$ & $\mathrm{~S}$ & $G$ \\
\hline CPD & G & $P$ & G & G & $\mathrm{S}$ & $\mathrm{S}$ & G & $\mathrm{P}$ & G & G & A & $\mathrm{S}$ & G & $P$ & G & G & $S$ & G \\
\hline DA & G & $S$ & $E$ & G & $\mathrm{S}$ & $\mathrm{S}$ & G & $\mathrm{S}$ & $E$ & $\mathrm{E}$ & $\mathrm{S}$ & A & G & $\mathrm{S}$ & G & G & $\mathrm{S}$ & G \\
\hline DD & $E$ & $\mathrm{P}$ & E & E & $\mathrm{S}$ & A & E & $\mathrm{P}$ & E & E & A & $\mathrm{S}$ & E & $\mathrm{S}$ & E & E & $\mathrm{S}$ & G \\
\hline FA & $E$ & $P$ & $E$ & G & $S$ & $\mathrm{~S}$ & $E$ & $\mathrm{P}$ & $E$ & $E$ & A & $\mathrm{S}$ & G & $\mathrm{S}$ & G & $G$ & A & $E$ \\
\hline FF & $E$ & $P$ & E & G & A & A & $\mathrm{E}$ & $\mathrm{P}$ & $\mathrm{E}$ & $\mathrm{E}$ & A & $\mathrm{S}$ & $G$ & $\mathrm{P}$ & G & $G$ & $\mathrm{~S}$ & G \\
\hline $\mathrm{FH}$ & $E$ & $S$ & $G$ & $E$ & A & $S$ & $E$ & $S$ & G & G & A & $S$ & G & $\mathrm{P}$ & G & G & $S$ & G \\
\hline GB & $E$ & $S$ & $\mathrm{~S}$ & G & A & $\mathrm{S}$ & $E$ & $\mathrm{~S}$ & $G$ & $G$ & $\mathrm{~S}$ & $\mathrm{~S}$ & G & $\mathrm{S}$ & G & $\mathrm{G}$ & $\mathrm{S}$ & G \\
\hline HA & G & $S$ & $\mathrm{~S}$ & $\mathrm{E}$ & A & $\mathrm{S}$ & G & $\mathrm{S}$ & G & G & A & $\mathrm{S}$ & $\mathrm{G}$ & $\mathrm{S}$ & G & G & $\mathrm{S}$ & G \\
\hline HB & $E$ & $S$ & $E$ & G & A & $\mathrm{S}$ & $E$ & $\mathrm{~S}$ & $E$ & $E$ & A & $\mathrm{S}$ & G & $\mathrm{S}$ & G & G & $S$ & G \\
\hline $\mathrm{HH}$ & $E$ & $S$ & $\mathrm{~S}$ & G & A & $\mathrm{S}$ & $\mathrm{E}$ & $\mathrm{S}$ & $\mathrm{G}$ & G & $\mathrm{S}$ & $\mathrm{S}$ & G & $\mathrm{S}$ & G & G & $\mathrm{S}$ & G \\
\hline JS & $G$ & $P$ & $E$ & $E$ & $\mathrm{~S}$ & $\mathrm{~S}$ & $G$ & $\mathrm{P}$ & $E$ & $E$ & A & $\mathrm{S}$ & $E$ & $\mathrm{P}$ & $E$ & $G$ & $\mathrm{~S}$ & $G$ \\
\hline $\mathrm{KN}$ & $E$ & $P$ & $E$ & G & $\mathrm{S}$ & $S$ & $E$ & $\mathrm{P}$ & $E$ & $E$ & A & $\mathrm{S}$ & $G$ & $\mathrm{P}$ & G & $G$ & $\mathrm{~S}$ & G \\
\hline LHA & $E$ & $S$ & $G$ & G & A & A & $\mathrm{E}$ & $\mathrm{S}$ & $\mathrm{G}$ & $G$ & A & $\mathrm{S}$ & $G$ & $\mathrm{~S}$ & $\mathrm{G}$ & $G$ & $\mathrm{~S}$ & G \\
\hline MAB & G & $P$ & G & E & G & A & G & $\mathrm{P}$ & G & G & A & $\mathrm{S}$ & G & $\mathrm{S}$ & G & G & $\mathrm{S}$ & G \\
\hline MK & $E$ & $\mathrm{P}$ & E & G & A & A & E & $\mathrm{P}$ & $E$ & E & A & $\mathrm{S}$ & G & $\mathrm{P}$ & G & G & $\mathrm{S}$ & G \\
\hline NANF & $E$ & $P$ & $E$ & G & $\mathrm{S}$ & A & $E$ & $\mathrm{P}$ & $E$ & $E$ & $\mathrm{~A}$ & $\mathrm{~S}$ & G & $\mathrm{S}$ & G & G & $\mathrm{S}$ & G \\
\hline $\mathrm{NH}$ & $E$ & $S$ & E & E & A & S & E & $\mathrm{S}$ & E & E & S & $\mathrm{S}$ & E & S & E & $\mathrm{E}$ & S & G \\
\hline
\end{tabular}

Table 4 shows the numerical weights of the employees' performances on individual criteria; the second last column of the table provides the overall weight of the employees. From the weights, employees' ranking can be obtained which has been shown in the last column. The HR department recognized that although the AHP application exercise has taken more time than the previously adopted technique, the procedure has generated a more reliable set of information on which to base its decision. 
Table 4: Overall Weights and Ranking of the 25 Employees

\begin{tabular}{|c|c|c|c|c|c|c|c|c|c|c|c|c|}
\hline \multirow[t]{2}{*}{ Empl. } & \multicolumn{3}{|c|}{$\mathrm{C}_{1}$} & \multicolumn{3}{|c|}{$\mathrm{C}_{2}$} & \multicolumn{3}{|c|}{$\mathrm{C}_{3}$} & \multicolumn{3}{|c|}{$\mathrm{C}_{4}$} \\
\hline & $\mathrm{C}_{11}$ & $\mathrm{C}_{12}$ & $\mathrm{C}_{13}$ & $\mathrm{C}_{21}$ & $\mathrm{C}_{22}$ & $\mathrm{C}_{23}$ & $\mathrm{C}_{31}$ & $\mathrm{C}_{32}$ & $\mathrm{C}_{33}$ & $\mathrm{C}_{41}$ & $\mathrm{C}_{42}$ & $\mathrm{C}_{43}$ \\
\hline AAD & 0.1011 & 0.0039 & 0.0093 & 0.0840 & 0.0076 & 0.0020 & 0.0284 & 0.0011 & 0.0026 & 0.0132 & 0.0015 & 0.0003 \\
\hline ABA & 0.1933 & 0.0021 & 0.0093 & 0.0840 & 0.0038 & 0.0020 & 0.0544 & 0.0006 & 0.0026 & 0.0067 & 0.0015 & 0.0003 \\
\hline AGS & 0.1933 & 0.0021 & 0.0093 & 0.0440 & 0.0076 & 0.0010 & 0.0544 & 0.0006 & 0.0026 & 0.0132 & 0.0015 & 0.0003 \\
\hline BA & 0.1933 & 0.0021 & 0.0178 & 0.0440 & 0.0038 & 0.0020 & 0.0544 & 0.0006 & 0.0050 & 0.0252 & 0.0029 & 0.0003 \\
\hline BA & 0.1011 & 0.0039 & 0.0093 & 0.0440 & 0.0038 & 0.0020 & 0.0284 & 0.0043 & 0.0026 & 0.0132 & 0.0029 & 0.0003 \\
\hline BB & 0.1933 & 0.0021 & 0.0093 & 0.0223 & 0.0038 & 0.0020 & 0.0544 & 0.0006 & 0.0026 & 0.0132 & 0.0015 & 0.0003 \\
\hline BK & 0.1933 & 0.0021 & 0.0093 & 0.0223 & 0.0038 & 0.0020 & 0.0544 & 0.0006 & 0.0026 & 0.0132 & 0.0029 & 0.0003 \\
\hline $\mathrm{CI}$ & 0.10 & 0.0021 & 0.00 & 0.0840 & 0.0038 & 0.0020 & 0.0284 & 0.0006 & 0.0026 & 0.0132 & 0.0015 & 0.0003 \\
\hline CPD & 0.1011 & 0.0021 & 0.0093 & 0.0440 & 0.0038 & 0.0010 & 0.0284 & 0.0006 & 0.0026 & 0.0132 & 0.0029 & 0.0003 \\
\hline DA & 0.1011 & 0.0039 & 0.0178 & 0.0440 & 0.0038 & 0.0010 & 0.0284 & 0.0011 & 0.0050 & 0.0252 & 0.0015 & 0.0006 \\
\hline DD & 0.1933 & 0.0021 & 0.0178 & 0.0840 & 0.0038 & 0.0020 & 0.0544 & 0.0006 & 0.0050 & 0.0252 & 0.0029 & 0.0003 \\
\hline FA & 0.1933 & 0.0021 & 0.0178 & 0.0440 & 0.0038 & 0.0010 & 0.0544 & 0.0006 & 0.0050 & 0.0252 & 0.0029 & 0.0003 \\
\hline FF & 0.1933 & 0.0021 & 0.0178 & 0.0440 & 0.0076 & 0.0020 & 0.0544 & 0.0006 & 0.0050 & 0.0252 & 0.0029 & 0.0003 \\
\hline FH & 0.1933 & 0.0039 & 0.0093 & 0.0840 & 0.0076 & 0.0010 & 0.0544 & 0.0011 & 0.0026 & 0.0132 & 0.0029 & 0.0003 \\
\hline GB & 0.1933 & 0.0039 & 0.0024 & 0.0440 & 0.0076 & 0.0010 & 0.0544 & 0.0011 & 0.0026 & 0.0132 & 0.0015 & 0.0003 \\
\hline HA & 0.1011 & 0.0039 & 0.0024 & 0.0840 & 0.0076 & 0.0010 & 0.0284 & 0.0011 & 0.0026 & 0.0132 & 0.0029 & 0.0003 \\
\hline $\mathrm{HB}$ & 0.1933 & 0.0039 & 0.0178 & 0.0440 & 0.0076 & 0.0010 & 0.0544 & 0.0011 & 0.0050 & 0.0252 & 0.0029 & 0.0003 \\
\hline $\mathrm{HH}$ & 0.1933 & 0.0039 & 0.0024 & 0.0440 & 0.0076 & 0.0010 & 0.0544 & 0.0011 & 0.0026 & 0.0132 & 0.0015 & 0.0003 \\
\hline JS & 0.101 & 0.0021 & 0.01 & 0.0840 & 0.0038 & 0.0010 & 0.0284 & 0.0006 & 0.0050 & 0.0252 & 0.0029 & 0.0003 \\
\hline $\mathrm{KH}$ & 0.193 & 0.0021 & 0.0178 & 0.0440 & 0.0038 & 0.0010 & 0.0544 & 0.0006 & 0.0050 & 0.0252 & 0.0029 & 0.0003 \\
\hline LHA & 1933 & 0.0039 & 0.00 & 0.0440 & 0.0076 & 0.0020 & 0.0544 & 0.0011 & 0.0026 & 0.0132 & 0.0029 & 0.0003 \\
\hline MAB & 0.1011 & 0.0021 & 0.0093 & 0.0840 & 0.0149 & 0.0020 & 0.0284 & 0.0006 & 0.0026 & 0.0132 & 0.0029 & 0.0003 \\
\hline MK & 1933 & 0.0021 & 0.0178 & 0.0440 & 0.0076 & 0.0020 & 0.0544 & 0.0006 & 0.0050 & 0.0252 & 0.0029 & 0.0003 \\
\hline NANF & 0.1933 & 0.0021 & 0.0178 & 0.0440 & 0.0038 & 0.0020 & 0.0544 & 0.0006 & 0.0050 & 0.0252 & 0.0029 & 0.0003 \\
\hline $\mathrm{NH}$ & 0.1933 & 0.0039 & 0.0178 & 0.0840 & 0.0076 & 0.0010 & 0.0544 & 0.0011 & 0.0050 & 0.0252 & 0.0015 & 0.0003 \\
\hline
\end{tabular}

Table 4: Continued

\begin{tabular}{|c|c|c|c|c|c|c|c|c|}
\hline \multirow{2}{*}{ Empl. } & \multicolumn{3}{|c|}{$\mathrm{C}_{5}$} & \multicolumn{3}{|c|}{$\mathrm{C}_{6}$} & \multirow{2}{*}{$\begin{array}{l}\text { Overall } \\
\text { Weights }\end{array}$} & \multirow[t]{2}{*}{ Rank } \\
\hline & $\mathrm{C}_{51}$ & $\mathrm{C}_{52}$ & $\mathrm{C}_{53}$ & $\mathrm{C}_{61}$ & $\mathrm{C}_{62}$ & $\mathrm{C}_{63}$ & & \\
\hline AAD & 0.0102 & 0.0002 & 0.0010 & 0.0040 & 0.0002 & 0.0003 & 0.2709 & 20 \\
\hline ABA & 0.0102 & 0.0004 & 0.0010 & 0.0040 & 0.0002 & 0.0003 & 0.3767 & 4 \\
\hline AGS & 0.0102 & 0.0002 & 0.0010 & 0.0040 & 0.0002 & 0.0003 & 0.3458 & 13 \\
\hline BA & 0.0052 & 0.0004 & 0.0005 & 0.0020 & 0.0002 & 0.0003 & 0.3600 & 11 \\
\hline BA & 0.0052 & 0.0004 & 0.0005 & 0.0020 & 0.0002 & 0.0003 & 0.2244 & 25 \\
\hline BB & 0.0052 & 0.0004 & 0.0005 & 0.0020 & 0.0002 & 0.0003 & 0.3140 & 17 \\
\hline BK & 0.0052 & 0.0002 & 0.0005 & 0.0020 & 0.0002 & 0.0003 & 0.3152 & 16 \\
\hline CI & 0.0102 & 0.0002 & 0.0010 & 0.0040 & 0.0002 & 0.0003 & 0.2648 & 21 \\
\hline CPD & 0.0102 & 0.0002 & 0.0010 & 0.0040 & 0.0002 & 0.0003 & 0.2252 & 24 \\
\hline DA & 0.0102 & 0.0004 & 0.0010 & 0.0040 & 0.0002 & 0.0003 & 0.2495 & 23 \\
\hline $\mathrm{DD}$ & 0.0195 & 0.0004 & 0.0019 & 0.0076 & 0.0002 & 0.0003 & 0.4213 & 2 \\
\hline FA & 0.0102 & 0.0004 & 0.0010 & 0.0040 & 0.0003 & 0.0006 & 0.3669 & 9 \\
\hline $\mathrm{FF}$ & 0.0102 & 0.0002 & 0.0010 & 0.0040 & 0.0002 & 0.0003 & 0.3711 & 6 \\
\hline $\mathrm{FH}$ & 0.0102 & 0.0002 & 0.0010 & 0.0040 & 0.0002 & 0.0003 & 0.3895 & 3 \\
\hline GB & 0.0102 & 0.0004 & 0.0010 & 0.0040 & 0.0002 & 0.0003 & 0.3414 & 14 \\
\hline $\mathrm{HA}$ & 0.0102 & 0.0004 & 0.0010 & 0.0040 & 0.0002 & 0.0003 & 0.2646 & 22 \\
\hline $\mathrm{HB}$ & 0.0102 & 0.0004 & 0.0010 & 0.0040 & 0.0002 & 0.0003 & 0.3726 & 5 \\
\hline $\mathrm{HH}$ & 0.0102 & 0.0004 & 0.0010 & 0.0040 & 0.0002 & 0.0003 & 0.3414 & 15 \\
\hline JS & 0.0195 & 0.0002 & 0.0019 & 0.0040 & 0.0002 & 0.0003 & 0.2983 & 18 \\
\hline $\mathrm{KH}$ & 0.0102 & 0.0002 & 0.0010 & 0.0040 & 0.0002 & 0.0003 & 0.3663 & 10 \\
\hline LHA & 0.0102 & 0.0004 & 0.0010 & 0.0040 & 0.0002 & 0.0003 & 0.3507 & 12 \\
\hline MAB & 0.0102 & 0.0004 & 0.0010 & 0.0040 & 0.0002 & 0.0003 & 0.2775 & 19 \\
\hline MK & 0.0102 & 0.0002 & 0.0010 & 0.0040 & 0.0002 & 0.0003 & 0.3711 & 7 \\
\hline NANF & 0.0102 & 0.0004 & 0.0010 & 0.0040 & 0.0002 & 0.0003 & 0.3675 & 8 \\
\hline $\mathrm{NH}$ & 0.0195 & 0.0004 & 0.0019 & 0.0076 & 0.0002 & 0.0003 & 0.4250 & 1 \\
\hline
\end{tabular}


In the following, we compile a number of advantages that have been identified while applying AHP at ISMS.

- $\quad$ AHP can accommodate subjective criteria quite well.

- AHP is systematic and thorough. If represents a complicated decision making problem into a hierarchy, which in turn, comprise the salient elements of the decision making problem. The hierarchy is viewed as logical and organized form in representing the problem. The model ensures that the decision maker will not overlook important factors in course of making decision.

- AHP can synthesize an alternative's scores on diverse criteria having heterogeneous measurement units; the outcome of the synthesis exercise is an overall score of the alternative.

- AHP compares two decision elements (criteria/alternatives) at a time. In this way, the decision maker becomes more focused and consequently the accuracy and reliability of the results are improved. Chan and Lynn (1991, p. 67) write: "The use of the analytic hierarchy process for multi-criteria rating is superior to other multiple attribute scoring models or to ad hoc weighting because it has the advantage of forcing the decision maker to focus exclusively on two objects at a time and the way in which they relate to each other, which is simpler and more manageable process than comparing five, twelve or twenty objects simultaneously."

- $\quad$ AHP is simple and easy to apply.

- AHP does not require the decision maker to be artificially consistent and at the end it provides an index measuring the amount of inconsistency.

- AHP can easily accommodate multiple decision makers to solve a particular problem.

- The ranking of the employees obtained at the end of the exercise can be considered as a basis for giving bonus to the employees.

- AHP amalgamates the performance criteria systematically, based on the pooling of inputs from various constituents.

Chan and Lynn (1991, p. 67) again comments on the applicability of AHP as a performance evaluation tool:

Probably the model's most important contribution to performance evaluation, however, is that it provides a systematic approach for weighting performance criteria to provide a comprehensive performance measure.

In particular, the reaction of the managing director of the company on the application of AHP at his company is the following:

... the benefits of the analytic hierarchy process are that it is a sound analytical method of making decisions between alternatives; it eliminates some of the mistakes in making management decision; it considers both tangible and intangible factors and this method utilizes thoughts and intuition in a logical fashion.

\section{Conclusion}

Employee performance appraisal system is generally considered to be essential in organizations and it is used for several different purposes such as pay increases, improvement and training, transfers, compensations, counseling, promotion, employee recognition, termination, etc. These purposes represent legitimate reasons for using performance appraisal systems in organizations. A simple and effective appraisal system that emphasizes continuous professional development enhances a firm's overall performance. However, performance evaluation process should be ongoing throughout the year. Even if a formal evaluation is given only once a year, an employee should be made aware of his or her performance periodically throughout the year. Furthermore, it must be remembered that the evaluation is not solely based on the employee's performance in the two-to three-week period before the evaluation, but is based on the employee's work during the appraisal period, whether it is three, six, or 12 months. The guidelines cited in this paper, if followed, are expected to assist in keeping a performance appraisal 
system responsive to organizations' needs. It is also expected that the personnel decisions based upon the results of the appraisal exercise will be much better and informed which will lead to greater organizational goal achievement. Over time, weaknesses occur in every system. Therefore, to have an effective appraisal system, it should be closely monitored and feedback should be obtained on the continuous basis. Finally, the management of ISMS believes that AHP application for performance appraisal at the company has been a successful one which has increased the accuracy and fairness of the process. In view of this, the management would like to extend the application to its Malacca and Pahang branches.

\section{References}

Aldakhilallah, K.A. and Parente, D.H. (2002) "Redesigning A Square Peg: Total Quality Management Performance Appraisals,” Total Quality Management, 13(1), 39-51.

Bahurmoz, A.M.A. (2003) “The Analytic Hierarchy Process at Dar Al-Hekma, Saudi Arabia,” Interfaces, 33(4), 70-78.

Camardella, M.J. (2003) “Effective Management of the Performance Appraisal Process," Employment Relations Today, 30(1), 103-107.

Chan, Y.C.L and Lynn, B.E. (1991) "Performance Evaluation and the Analytic Hierarchy Process," Journal of Management Accounting Research, 57-87.

Daley, D. M. (1993) "Performance Appraisal As an Aid in Personnel Decisions," American Review of Public Administration, 23, 201-214.

Deming, W.E. (1986) Out of the Crisis, Cambridge, Mass: MIT Center for Advanced Engineering Study.

Dobbins, G.H., Cardy, R.L. and Platz-vieno, S.J. (1990) “A Contingency Approach to Appraisal Satisfaction: An Initial Investigation of the Joint Effects of Organizational Variables and Appraisal Characteristics," Journal of Management, 16, 619-632.

Glaser, M. (1993) "Reconciliation of Total Quality Management and Traditional Performance Tools," Public Productivity and Management Review, 26, 379-386.

Gray, G. (2002) “Performance Appraisals Don’t Work,” Industrial Management, 15-17.

Hallyer, M. and Brewer, B. (1991) "Performance Appraisal in the Hong Kong Civil Service - An Appraisal of the G.F. 1 System," Civil Service Systems in Asia Pacific - An International Workshop, April 15-17.

Jordan, J.L. (1992) “Performance Appraisal Satisfaction and Supervisor's Traits," Psychological Reports, 66, 1337-1338.

Kane, J.S. and Kane, K.F. (1992) "TQM-Compatible Performance Appraisal: An American Culture Imperative,” Journal of Management Systems, 4, 11-28.

Krug, J. (1998) “Improving the Performance Appraisal Process,” Journal of Management in Engineering, $19-20$.

Landy, F. and Farr, J. (1983) The Measurement of Work Performance, NY: Academic Press.

Lansbury, R. (1988) “Performance Management: A Process Approach,” Human Resource Management, Australia, 46-55. 
Longenecker, C.O. and Fink, L.S. (1999) “Creative Effective Performance Appraisals," Industrial Management, 18-23.

Mani, B.G. (2002) "Performance Appraisal Systems, Productivity, and Motivation: A Case Study," Public Personnel Management, 31(2), 141-159.

Martin, D.C. and Bartol, K.M. (1998) "Performance Appraisal: Maintaining System Effectiveness," Public Personnel Management, 27(2), 223-230.

McCarthy, J. (2000) "How to Conduct Productive Performance Appraisals," Journal of Property Management, 22-25.

Meyer, A. (1995) “An Employee Evaluation Tool that Works,” Nursing Homes, 44(2), 14-17.

Milliman, J.F., Zawacki, R.F., Norman, C., Powell, L. and Kirksey, J. (1994) "Companies Evaluate Employees from All Perspectives,” Personnel Journal, 73(11), 99-103.

Murphy, K. and Cleveland, J. (1991) Performance Appraisal: An Organizational Perspective, Boston: Allyn and Bacon.

Patten, T. (Jr.) (1977) Pay: Employee Compensation and Incentive Plans, London: The Free Press.

Petrie, F. (1950) “Is There Something New in Efficiency Rating?” Personnel Administrator, 13, 24.

Rangone, A. (1996) "An Analytical Hierarchy Process Framework for Comprising the Overall Performance of Manufacturing Departments," International Journal of Operations and Production Management, 16 (8), 104-119.

Roberts, G.E. (1994) "Maximizing Performance Appraisal System Acceptances, Perspectives from Municipal Government Personnel Administrators,” Public Personnel Management, 23, 525-549.

Roberts, G.E. (2003) “Employee Performance Appraisal System Participation: A Technique that Works,” Public Personnel Management, 32(1), 89-98

Saaty, T.L. (1990) "How to Make A Decision: The Analytic Hierarchy Process", European Journal of Operational Research, 48, 9-26.

Somerick, N.M. (1993) "Strategies for Improving Employee Relations by Using Performance Appraisals More Effectively,” Public Relations Quarterly, 38 (3), 37-39.

Stevens, M. (1990) “Evaluating Employees from the Outside in,” Small Business Reports, 15(8), 14-16.

Suwignjo, P., Bititci, U.S. and Carrie, A.S. (2000) "Qualitative Models for Performance Management System,” International Journal of Production Economics, 64, 231-241.

Taylor III, Frank A., Ketcham, Allen F. and Hoffman, D. (1998) "Personnel Evaluation with AHP," Management Decision, 36 (10), 679-685.

Vallance, S. (1999) Performance Appraisal in Singapore, Thailand and the Philippines: A Culture Perspective,” Australian Journal of Public Administration, 58(3), 78-95. 